\title{
Contribution of primary producers to mercury trophic transfer in estuarine ecosystems: Possible effects of eutrophication
}

\author{
J.P. Coelho ${ }^{\text {a, } *}$, M.E. Pereira ${ }^{\text {a }}$, A.C. Duarte ${ }^{\text {a }}$, M.A. Pardal ${ }^{\text {b }}$ \\ ${ }^{a}$ CESAM E' Chemistry Department, Campus de Santiago, University of Aveiro, 3810-193 Aveiro, Portugal \\ ${ }^{\mathrm{b}}$ IMAR - Institute of Marine Research, Zoology Department, University of Coimbra, 3004 - 517 Coimbra, Portugal
}

\section{A R T I C L E I N F O}

\section{Keywords:}

Salt marsh plants

Seagrasses

Macroalgae

Eutrophication

Mercury

Food webs

\begin{abstract}
A B S T R A C T
There is an ongoing eutrophication process in the Ria de Aveiro coastal lagoon (Portugal), with progressive replacement of rooted primary producers for macroalgae. Taking advantage of a well-defined environmental contamination gradient, we studied mercury accumulation and distribution in the aboveground and the belowground biomass of several salt marsh plants, including the seagrass species Zostera noltii and the dominant green macroalgal species Enteromorpha sp. The results of these experiments were then placed into the context of the estuarine mercury cycle and transport from the contaminated area.

All salt marsh plants accumulated mercury in the root system, with Halimione portulacoides showing the highest levels, with up to $1.3 \mathrm{mg} \mathrm{kg}^{-1}$ observed in the most contaminated area. Belowground/aboveground ratios were generally below 0.4 , suggesting that salt marsh plants are efficient immobilizers and retainers of mercury agents. Moreover, due to their sediment accretion capacities, salt marsh plants seem to play an important role in the sequestration of mercury in estuarine sediments.

Seagrasses, on the other hand, accumulated considerable amounts of mercury in the aboveground biomass with belowground/aboveground ratios reaching as high as 1.4 . These results may be due to their different routes of uptake (roots and foliar uptake) which suggests that seagrass meadows can be an important agent in the export of mercury from contaminated areas, considering the high aboveground biomass replacement rates.

Rooted macrophytes accumulate less mercury in their aboveground biomass than macroalgae. The change of primary producer dominance due to eutrophication can originate a 4- to 5-fold increase in primary producer associated mercury. This mercury would be available for export, making it bioavailable to estuarine food webs, which stresses the need to reverse the current eutrophic status of estuarine systems.
\end{abstract}

(c) 2008 Elsevier Ltd. All rights reserved.

\section{Introduction}

Multiple anthropogenic pressures, such as human population growth, increased industrialization and intensive agriculture, are endangering aquatic environments and have promoted a growing international consciousness toward assessing the status of the areas and protecting these ecosystems. Excessive nutrient loading of coastal systems is a global concern, as it can lead to harmful macroalgal blooms and shifts in primary producer communities from stable macrophyte based systems to highly dynamic macroalgae dominated systems (Cardoso et al., 2004; Pardal et al., 2004). The fate and effects of pollutants are also a research priority, and in this area, mercury stands out as one of the most toxic, with rec-

\footnotetext{
* Corresponding author. Tel.: +351 234370737; fax: +351 234370084 .

E-mail address: jpcoelho@ua.pt (J.P. Coelho).
}

ognized mutagenic and teratogenic effects (Calderón et al., 2003; Tchounwou et al., 2003).

The use of estuarine primary producers, namely macroalgae, seagrasses and salt marsh plants, to monitor the environmental quality of aquatic environments has been widely discussed (Caçador et al., 2000; Fitzgerald et al., 2003; Almeida et al., 2006; Kaldy, 2006; Quan et al., 2007). Each group of primary producers will be sensitive to different environmental compartments, depending on the primary sorption mechanisms, which will result in differential responses to contamination. Macroalgae have been considered efficient biomonitors of dissolved metal sources (Rainbow and Phillips, 1993; Leal et al., 1997; Conti and Cecchetti, 2003; Gosavi et al., 2004; Runcie and Riddle, 2004; Coelho et al., 2005), and seagrasses may reflect both dissolved contaminants and sediment contaminant loads since they can accumulate toxins in the root system and through the aerial parts of the plant. In a study by Lafabrie et al. (2008) in the Mediterranean, the seagrass Posidonia oceanica 
preferentially accumulated metals in the leaves, which suggested that the plant was taking up metals from the water column. In another study (Lafabrie et al., 2007), the same species was found to reflect contamination both in the water column $(\mathrm{Cd}, \mathrm{Pb})$ and in the sediment $(\mathrm{Co}, \mathrm{Cr}, \mathrm{Hg}$, and $\mathrm{Ni}$ ). Salt marsh plants, in turn, will reflect mainly sediment contaminant loads, rather than the dissolved fraction, given their uptake route through the root system. Some research has been performed on the genera Spartina and Phragmites (Caçador et al., 2000; Weis et al., 2002; Fitzgerald et al., 2003; Windham et al., 2003; Quan et al., 2007), which accumulate metals essentially in the belowground biomass and restrict their translocation to the photosynthetic parts of the organism.

Primary producers are the base of the estuarine trophic webs and may therefore represent an important pathway for mercury incorporation into the biota, since the incorporated metal will be available either through herbivory or through the detritivore food web as decaying plant detritus (Coelho et al., 2005). Excluding their use as forage (Kuijper et al., 2008), only a few species have the ability to feed directly on living salt marsh plants (Thayer et al., 1984; Lillebø et al., 1999), and thus, their nutrient and contaminant load will be available mainly to detritivores (Créach et al., 1997; Vizzini et al., 2002). However, seagrasses and macroalgae are actively grazed upon by a number of species, including waterfowl, fish and invertebrates (Thom et al., 1995; Vermaat and Verhagen, 1996; Heck and Valentine, 2006; MacArthur and Hyndes, 2007). This disparity in grazing pressure, coupled with the contrasting contamination sources for each type of primary producer, will result in distinct contributions to the transport and trophic transfer of mercury in estuarine ecosystems. Processes of plant succession mediated by eutrophication can consequently modify the mercury biogeochemical cycle and bioaccumulation potential.

Studies focusing on the role of primary producers in accumulation, transport and trophic transfer of contaminants are scarce, and those that take into consideration eutrophication-mediated plant succession are even rarer. Therefore, the main aim of this research was to study the mercury loads and distribution in salt marsh plants, seagrasses and macroalgae and to provide initial insight into their roles in the bioaccumulation processes. Results were discussed in light of existing knowledge on primary consumption, eutrophic succession and contaminant transport.

\section{Materials and methods}

\subsection{Study site characterization}

The study was conducted in the Ria de Aveiro coastal lagoon on the northwestern coast of Portugal (Fig. 1). For 50 years, the lagoon was subjected to continuous mercury discharges from a chlor-alkali industry, inducing an environmental contamination gradient inside the lagoon (Pereira et al., 1998b). Mercury storage in the system was estimated to be about $33 \times 10^{3} \mathrm{~kg}$, of which $77 \%$ is stored in the Estarreja channel and Laranjo Basin (Pereira et al., 1998a).

Apart from the mercury contamination concern, a drastic reduction in the seagrass-covered area is currently in progress, as a result of changes in physical forcing (da Silva et al., 2004). In addition, despite the fact that the overall nutrient status of the system is considered to be in the "moderate low" eutrophic condition

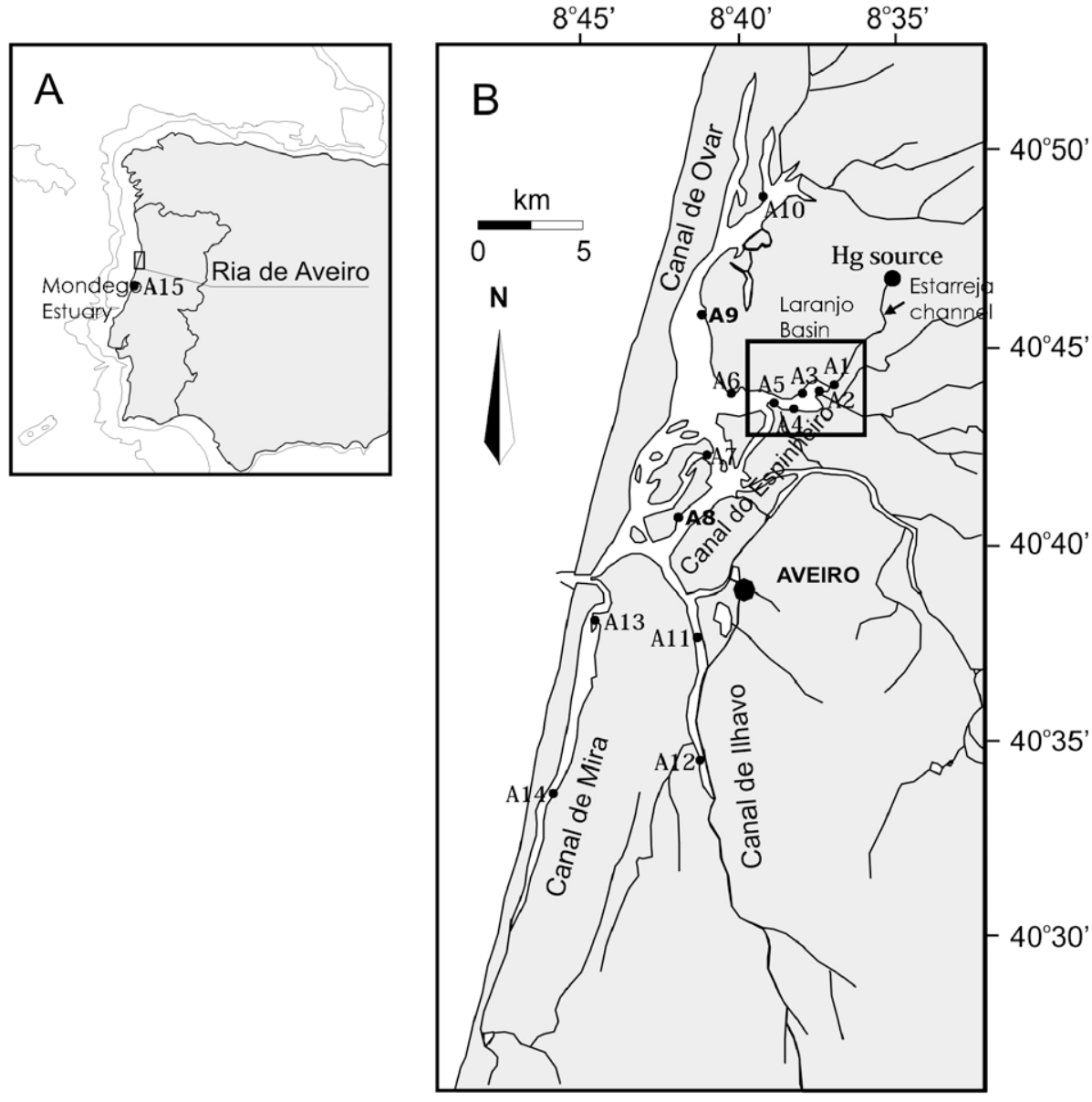

Fig. 1. The Ria de Aveiro coastal lagoon with the sampling sites and mercury source indicated. 
range, the trophic status of the inner areas is clearly higher (Lopes et al., 2007), which may favor macroalgal growth. Therefore, this system could be considered a privileged field laboratory to study the processes and effects of eutrophication on primary producer mercury accumulation and dynamics.

Fourteen sampling locations (A1 to A14, Fig. 1) were selected along the four main arms of the lagoon with special focus on the most contaminated area, the Laranjo Basin (stations A1 to A5), near Estarreja where the industrial mercury discharges occurred. In addition, one sampling station was selected in the Mondego Estuary (A15), $60 \mathrm{~km}$ south from the Ria de Aveiro. This station was found to have near pristine conditions concerning heavy metal contamination (Coelho et al., 2005, 2006) and was used as a reference site.

\subsection{Sampling procedures}

Biological samples (salt marsh species Halimione portulacoides, Spartina maritima, Arthrocnemum fruticosum and Juncus maritimus, seagrass Zostera noltii and green macroalgae Enteromorpha sp.) were randomly collected by hand from different patches at each sampling site. To account for variability within each site, samples were pooled in a single plastic bag. Sampling was conducted during low tide in late spring/early summer, when both perennial and seasonal plants where expected to be present. Salinity was recorded whenever possible in the low water pools near where the biological samples were collected, as well as in the adjacent channel. All samples were transported in coolers, and upon arrival at the laboratory, plant samples were carefully washed with gentle rubbing to remove adherent sediment and epiphytes. Tissues were differentiated and separated, dried to a constant weight in a forced air oven at $60^{\circ} \mathrm{C}$, homogenized and stored in acid washed plastic flasks until analysis could take place. Whenever possible, sediment samples were taken from the vicinity of the roots by collecting $30 \mathrm{~cm}$ deep cores $(15 \mathrm{~cm}$ diameter). In the laboratory, sediment samples were oven-dried to a constant weight at $60^{\circ} \mathrm{C}$, homogenized and sieved through a $1 \mathrm{~mm}$ sieve before storing. Water samples were transported to the laboratory and processed within a few hours. The water samples were filtered and acidified to $\mathrm{pH}<2$ with nitric acid, while the suspended particulate matter (SPM) was collected on a pre-weighed, $0.45 \mu \mathrm{m}$ pore size Millipore filter for mercury determinations.

\subsection{Analytical methods and quality control}

Total mercury in the sediment and in the biological samples was determined by thermal decomposition atomic absorption spectrometry after gold amalgamation, using a LECO AMA-254 (Advanced Mercury Analyzer).

Filters were oven-dried at $60{ }^{\circ} \mathrm{C}$ and digested with $4 \mathrm{~mol} \mathrm{~L}^{-1}$ $\mathrm{HNO}_{3}$ for determining the total mercury concentration in the suspended particulate matter. For detailed information on the method, please see Pereira et al. (1998a). Dissolved reactive mercury and suspended particulate matter mercury analyzes were performed by cold-vapor atomic fluorescence spectrometry (CVAFS) using a PSA model Merlin 10.023 equipped with a detector PSA model 10.003 , with tin chloride as reducing agent ( $2 \%$ in $10 \%$ $\mathrm{HCl})$.

Organic mercury levels in biological tissues were determined after sample digestion with a mixture of $18 \% \mathrm{KBr}$ in $5 \% \mathrm{H}_{2} \mathrm{SO}_{4}$, followed by extraction of organic mercury into toluene (for further details, see Válega et al., 2006). Mercury levels were measured by thermal decomposition atomic absorption spectrometry after gold amalgamation.

The accuracy and precision of both total and organic mercury determinations were assessed by analyzing aliquots of certified reference materials (CRM). The CRMs used for sediments were PACS-2 (polluted marine sediment, recovery: $102.7 \% \pm 6.4 \%$ at 0.05 significance level) and MESS-3 (marine sediment, recovery: $94.8 \% \pm 4.9 \%$ at 0.05 significance level). For biological samples, BCR - 60 (Lagarosiphon major, recovery: $90.7 \% \pm 3.3 \%$ at 0.05 significance level) and IAEA - 140TM (Fucus sp. homogenate, recovery: $85.0 \% \pm 9.5 \%$ at 0.05 significance level) were used. The results were corrected according to the daily recovery percentage of the CRM analyzes.

\section{Results}

\subsection{Abiotic environment}

The presence of a well-defined source of mercury contamination in the system has been reported previously (Pereira et al., 1998a), and our results are consistent with earlier findings. Environmental contamination in the water column and in sediments was found to decrease with distance from the source (Table 1). Dissolved reactive mercury ranged from 9 to $60 \mathrm{ng} \mathrm{L}^{-1}$ in the Laranjo Basin and never exceeded $5 \mathrm{ng} \mathrm{L}^{-1}$ outside this area. However, SPM mercury levels varied between 6 and $26 \mathrm{mg} \mathrm{kg}^{-1}$ in the contaminated area and were in the range of $1 \mathrm{mg} \mathrm{kg}^{-1}$ or below seawards from that area. Therefore, mercury contamination seems to be confined to the Laranjo Basin (A1-A5), while the downstream areas (A11-A14) are comparable to the reference site (A15).

Table 1

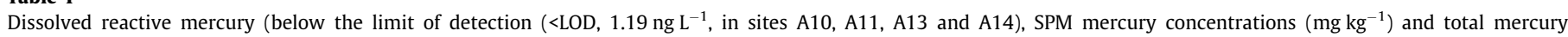
concentrations $\left(\mathrm{mg} \mathrm{kg}^{-1}\right)$ in non-vegetated and vegetated sediments.

\begin{tabular}{|c|c|c|c|c|c|c|c|c|}
\hline \multirow[t]{2}{*}{ Station } & \multirow{2}{*}{$\begin{array}{l}\text { Dissolved reactive } \\
\mathrm{Hg}\left(\mathrm{ng} \mathrm{L}^{-1}\right)\end{array}$} & \multirow{2}{*}{$\begin{array}{l}\text { Suspended particulate } \\
\text { matter } \mathrm{Hg}\left(\mathrm{mg} \mathrm{kg}^{-1}\right)\end{array}$} & \multicolumn{6}{|c|}{ Sediment $\mathrm{Hg}\left(\mathrm{mg} \mathrm{kg}^{-1}\right)$} \\
\hline & & & Non-vegetated & Halimione & Juncus & Spartina & Arthrocnemum & Zostera \\
\hline $\mathrm{A} 1$ & 60,5 & 25.8 & 51.7 & & & & & \\
\hline $\mathrm{A} 2$ & 15,8 & 20.1 & 6.8 & & 7.2 & & & \\
\hline A3 & 24,0 & 9.0 & 5.2 & & & & & \\
\hline A4 & 28,3 & 6.5 & 2.5 & & & & & \\
\hline A5 & 8,99 & 8.9 & 6.2 & 1.5 & 1.1 & 2.1 & & \\
\hline A6 & 2,93 & 1.1 & 0.35 & 1.5 & 1.5 & 0.15 & & 0.23 \\
\hline A7 & 3,95 & 0.7 & 0.06 & 0.65 & 0.88 & 1.2 & 0.52 & \\
\hline A8 & 2,65 & 0.8 & 0.19 & 0.17 & & 0.07 & 0.07 & \\
\hline A9 & & 0.8 & 0.10 & 0.61 & 1.4 & 1.1 & 0.93 & \\
\hline A10 & $<\mathrm{LOD}$ & 0.5 & 0.23 & 0.27 & 0.29 & & 0.24 & \\
\hline A11 & $<\mathrm{LOD}$ & 1.0 & 0.27 & 0.21 & 0.36 & 0.44 & 0.36 & \\
\hline A12 & 1,41 & 0.3 & 0.17 & 0.26 & & 0.26 & & \\
\hline A13 & $<$ LOD & 0.6 & 0.22 & 0.21 & & 0.17 & 0.05 & 0.11 \\
\hline A14 & $<$ LOD & 0.4 & 0.09 & & & 0.10 & & 0.08 \\
\hline A15 & 1,46 & 1.2 & 0.05 & & & & & \\
\hline
\end{tabular}


No significant differences were observed between plant-associated sediments ( $p=0.05$, Wilcoxon Signed Ranks Test). Nevertheless, outside the Laranjo Basin, non-vegetated sediments seem to be less contaminated than colonized sediments, which probably results from the sediment accretion properties of salt marsh plants. These primary producers can trap and immobilize mercury-rich suspended particles that are transported from the contaminated area, resulting in higher mercury levels than in non-vegetated sediments.

\subsection{Salt marsh plants}

All studied species essentially accumulated mercury in belowground tissues (Fig. 2), as previously observed by several authors (Caçador et al., 2000; Windham et al., 2003; Quan et al., 2007). Mercury concentrations in the roots ranged from 0.01 to $1.3 \mathrm{mg} \mathrm{kg}^{-1}$, with the highest levels detected in Halimione portucaloides. Mercury body burdens decreased with distance from the source in both $H$. portucaloides and J. maritimus, despite the significant negative correlation between mercury levels in roots and associated sediments in $H$. portucaloides (Spearman's correlation, $r=-0.88, \mathrm{p}=0.002$ ) and the lack of a significant linear correlation in J. maritimus. In contrast, S. maritima and A. fruticosum did not show a clear pattern of mercury accumulation in the root system despite the significant positive correlation with sediment contamination (Spearman's correlation, $r=0.68, p=0.042$ ) found in $S$. maritime. In the case of $S$. maritima and A. fruticosum, the highest contamination was observed far from the contaminated area. The mercury enrichment factor of roots, defined as $\mathrm{EF}=\left[\mathrm{Hg}_{\text {plant }}\right] /$ $\left[\mathrm{Hg}_{\text {sediment }}\right]$, is presented in Table 2 . These data show that $A$. fruticosum is the species that accumulates higher amounts of metal in the roots, while $J$. maritimus seems to be the least responsive species to the mercury gradient.

In the aboveground tissues, mercury concentrations never exceeded $0.2 \mathrm{mg} \mathrm{kg}^{-1}$ in the most contaminated area, which is considerably lower than the concentrations discovered in the belowground biomass. Stems were the least contaminated tissues, whereas old leaves showed, in general, a higher mercury load than young leaves. This trend was not true for J. maritimus in the contaminated area. Mercury accumulation was similar in aerial tissues, except in the case of the $S$. maritima stems, which had very low levels of mercury contamination, regardless of location. Given
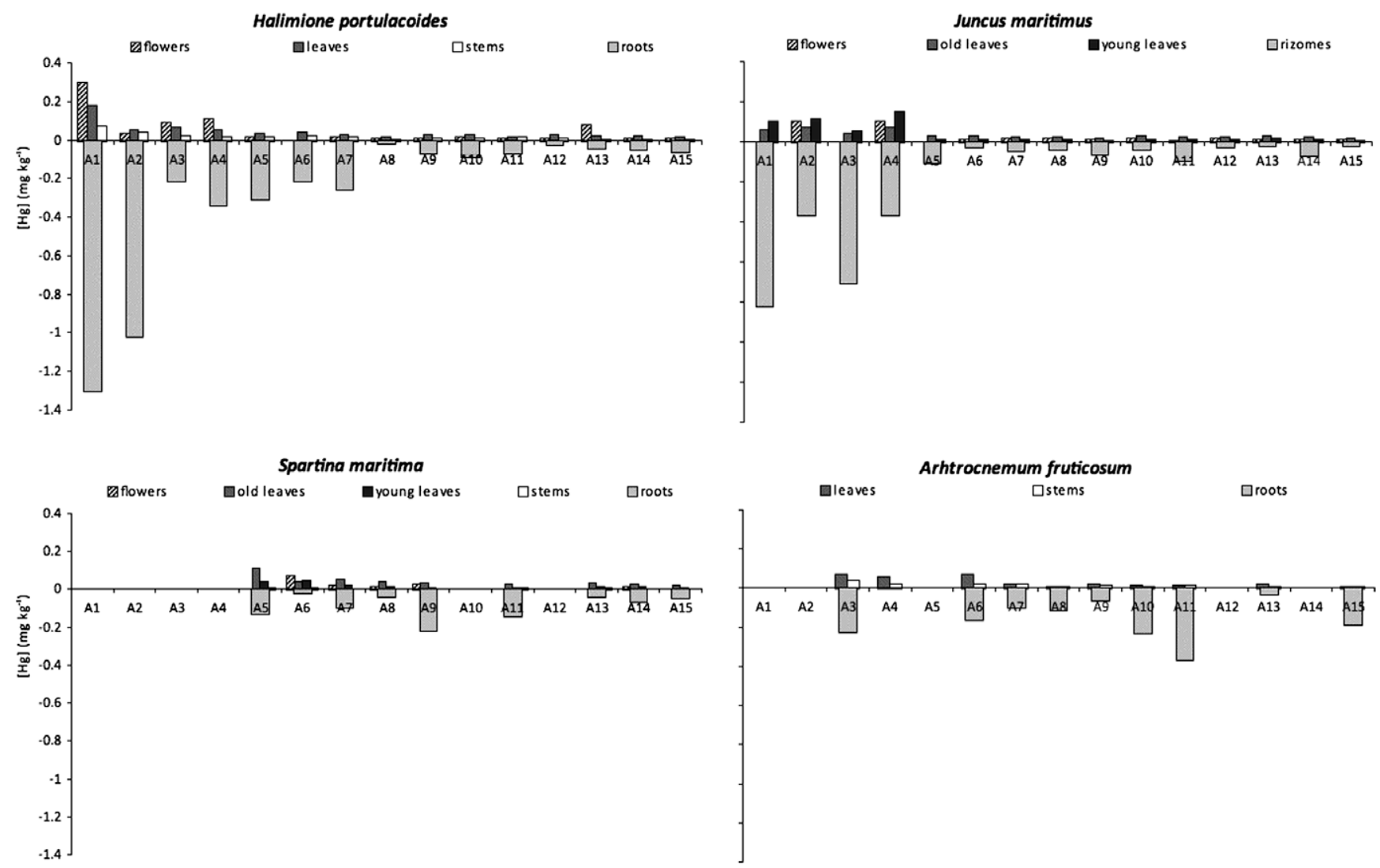

Fig. 2. Total mercury concentrations $\left(\mathrm{mg} \mathrm{kg}^{-1}\right.$ ) in belowground biomass and various aboveground tissues of salt marsh plants.

Table 2

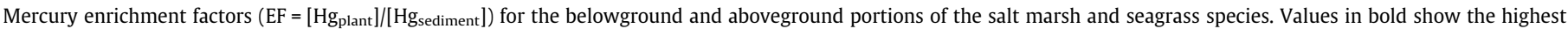
EFs.

\begin{tabular}{|c|c|c|c|c|c|c|}
\hline & & H. portucaloides & J. maritimus & S. maritima & A. fruticosum & Z. noltii \\
\hline \multirow[t]{3}{*}{ Above ground } & Max & 0.17 & 0.064 & 0.27 & 0.27 & 0.98 \\
\hline & Min & 0.015 & 0.0092 & 0.017 & 0.017 & 0.45 \\
\hline & Average & 0.057 & 0.026 & 0.10 & 0.093 & 0.68 \\
\hline \multirow[t]{3}{*}{ Below ground } & Max & 0.39 & 0.26 & 0.52 & 1.6 & 0.71 \\
\hline & Min & 0.089 & 0.018 & 0.062 & 0.063 & 0.50 \\
\hline & Average & 0.20 & 0.091 & 0.24 & 0.73 & 0.60 \\
\hline
\end{tabular}


the inconsistent pattern of accumulation in the root system for $S$. maritima and A. fruticosum, no significant correlations were found between the belowground mercury load and the aboveground tissue mercury average, contrary to what was observed for J. maritimus (Spearman's correlation, $r=0.70, p=0.016$ ) and $H$. portucaloides (Spearman's correlation, $r=0.76, p=0.001$ ).

Mercury enrichment factors for the aboveground biomass (Table 2) were low in all salt marsh species, which is contrary to what was observed for the roots. These results further highlighted the differential tissue accumulation occurring in all plants, since EFs for the aerial plant parts were at least half of the corresponding root EFs, reaching a 6-fold difference in the case of $A$. fruticosum.

\subsection{Seagrasses}

Zostera noltii seagrass meadows were only found in four out of the fourteen sampling sites in the Ria de Aveiro, which is evidence of a progressive reduction of this rich and sensitive habitat because of multiple environmental stressors (Cardoso et al., 2004; da Silva et al., 2004). Mercury concentrations ranged from 0.039 to $0.81 \mathrm{mg} \mathrm{kg}^{-1}$ in the roots and from 0.017 to $0.59 \mathrm{mg} \mathrm{kg}^{-1}$ in the aboveground biomass (Fig. 3). There was a consistent pattern of increased mercury loads in the senescent, older leaves. Mercury concentrations in all tissues correlated significantly with the sediment mercury load, but only the roots correlated negatively (Spearman's correlation, $r=-1, p=1 \times 10^{-6}$ ), which may suggest that aboveground biomass accumulation occurs from the dissolved fraction of mercury contamination. EFs for Z $Z$. noltii (Table 2) were higher for the aboveground fraction, although not statistically different (Mann-Whitney $U$-test, $\mathrm{p}=0.83$ ) from the belowground fraction. This pattern is in contrast to that of the salt marsh plants, which seem to prevent mercury translocation to the aerial parts of the organism.
Organic mercury was quantified only in site A3 (Table 3) and ranged from $0.010 \mathrm{mg} \mathrm{kg}^{-1}$ in the roots to $0.015 \mathrm{mg} \mathrm{kg}^{-1}$ in new leaves, with an average aboveground concentration of $0.014 \mathrm{mg} \mathrm{kg}^{-1}$. These results correspond to organic mercury fractions of $1.2 \%$ in roots, $2.3 \%$ in old leaves and $4.4 \%$ in new leaves.

\subsection{Macroalgae}

Macroalgae, namely Ulvoids (Enteromporpha sp.), are the dominant primary producers in most intertidal plains of the Ria de Aveiro, and they were present in all sampling sites. The highest mercury concentrations were found in this alga, reaching $2.1 \mathrm{mg} \mathrm{kg}^{-1}$ at the most contaminated site (Fig. 4). Body burdens decreased sharply with distance from the source, and for the macroalgae, they were below those observed for the $Z$. noltii aboveground biomass in the same area. Strong correlations were demonstrated between algal mercury burden and reactive dissolved mercury (Spearman's correlation, $r=0.75, p=0.012$ ), SPM (Spearman's correlation, $r=0.59, p=0.021$ ) and sediments (Spearman's correlation, $r=0.52, p=0.046$ ). The highest correlation coefficient suggests that the main mercury source for algae is the dissolved fraction. Organic mercury in sites A1-A5 (Table 3) ranged from $0.0066 \mathrm{mg} \mathrm{kg}^{-1}$ to $0.065 \mathrm{mg} \mathrm{kg}^{-1}$, with an average of $0.021 \mathrm{mg} \mathrm{kg}^{-1}$. These concentrations correspond to organic mercury fractions between $3.0 \%$ and $9.9 \%$, with an average of $6.4 \%$, which is higher than that observed for seagrasses.

Table 3 compares the mercury loads (per square meter) associated with the existing primary producers in the intertidal plains of the contaminated Laranjo Basin, seagrasses (only from site A3, the only remaining seagrass meadow of the area) and macroalgae (average concentration from sites A1-A5, due to the tidal mobility of the genus). Even though mercury concentrations are comparable, it is evident that the higher macroalgal biomass implies nearly

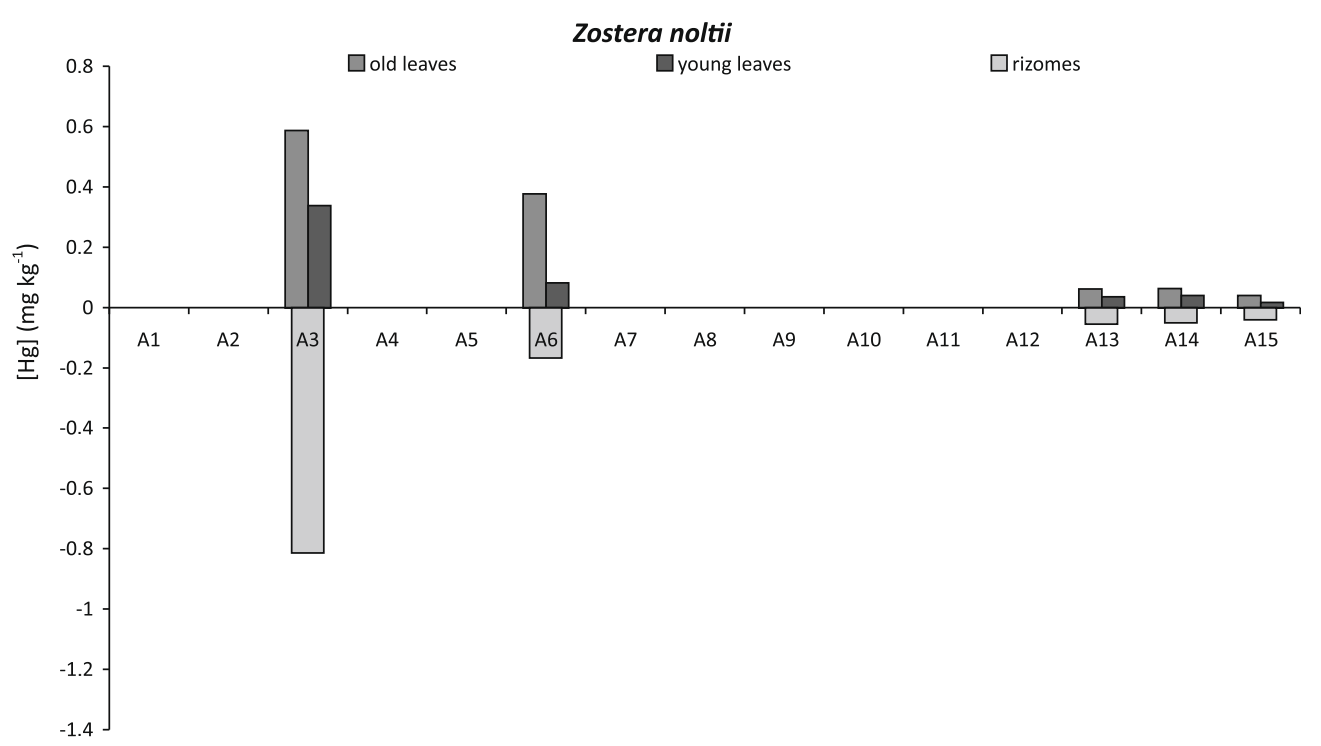

Fig. 3. Total mercury concentrations $\left(\mathrm{mg} \mathrm{kg}^{-1}\right)$ in belowground biomass and various aboveground tissues of Zostera noltii seagrass.

Table 3

Primary producer associated mercury in the intertidal plains of the contaminated area of the Ria de Aveiro (A1-A5).

\begin{tabular}{|c|c|c|c|c|c|}
\hline & {$[\mathrm{Hg}]_{\text {tot }}\left(\mathrm{mg} \mathrm{kg}^{-1}\right)$} & {$[\mathrm{Hg}]_{\text {org }}\left(\mathrm{mg} \mathrm{kg}^{-1}\right)$} & Biomass $\left(\mathrm{Kg} \mathrm{m}^{-2}\right)$ & Total mercury mass $\left(\mathrm{mg} \mathrm{m}^{-2}\right)$ & Organic mercury mass $\left(\mathrm{mg} \mathrm{m}^{-2}\right)$ \\
\hline Seagrasses & 0.46 & 0.014 & $0.15^{\mathrm{a}}$ & 0.069 & 0.0021 \\
\hline Macroalgae & 0.57 & 0.021 & 0.5 & 0.28 & 0.010 \\
\hline
\end{tabular}

\footnotetext{
${ }^{a}$ Data from da Silva et al. (2004).
} 


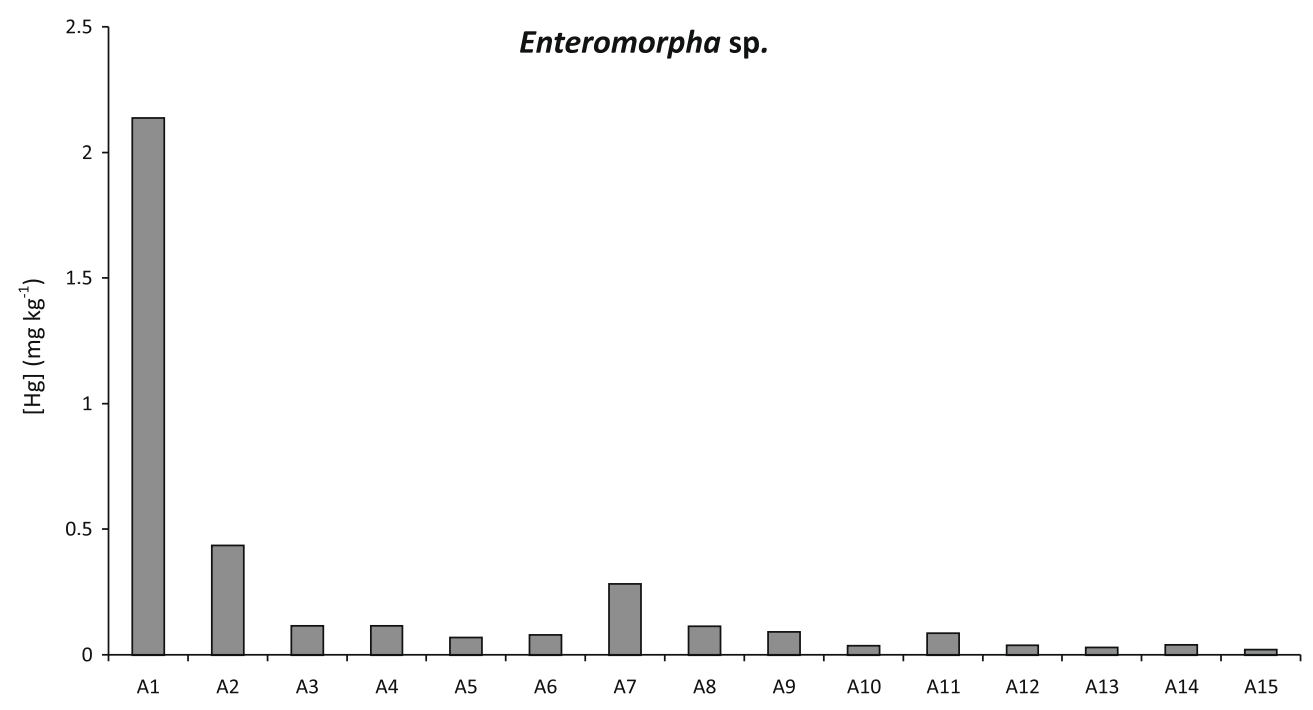

Fig. 4. Total mercury concentrations $\left(\mathrm{mg} \mathrm{kg}^{-1}\right)$ in the green macroalgae Enteromorpha sp.

a 4-fold increase, from 0.07 to $0.28 \mathrm{mg} \mathrm{m}^{-2}$, in the amount of mercury per square meter of intertidal plain associated with primary producers. Regarding organic mercury, this difference is increased to a 5 -fold change, from 0.0021 to $0.10 \mathrm{mg} \mathrm{m}^{-2}$, which may have important ecological implications for the system.

\section{Discussion}

Our results show a marked difference in the mercury accumulation patterns of salt marsh plants, seagrasses and macroalgae. All marsh plants accumulated mercury essentially in the root system, as reported previously for the same estuarine system (Válega et al., 2008) and for other systems (Windham et al., 2003; Canário et al., 2007). This ability to minimize metal translocation to photosynthetic tissues is a defense mechanism to prevent stress and adverse effects. Specifically, the plant can store the metal in cell walls and vacuoles or sequester it with metal binding proteins such as phytochelatins (Windham et al., 2003). Given the higher mercury load in belowground biomass, the metal will cycle between accumulation in the roots and remineralization through root decay. However, it will predominantly remain immobile in the sediments, a process reported by some authors as contaminant phytostabilization (Almeida et al., 2004, 2006; Weis and Weis, 2004). The wellknown sediment accretion capacities of salt marsh plants (Sanchez et al., 2001; Coelho et al., 2004; Hung and Chmura, 2006) further enhance this phytostabilization process by trapping metal-rich suspended particles. The trend in this study, where higher mercury concentrations are found in downstream plant-colonized sediments when compared to bare-bottom sediments, supports a mechanism such as the one discussed above, with mercury-rich suspended particles originating from the Laranjo Basin settling due to reduced water currents flowing through salt marshes. For all salt marsh plants, the low enrichment factor of aboveground biomass to sediment contamination (on average below 0.1 ) will reduce the pool of mercury that is associated with plant tissue and is thus available for transport or incorporation in estuarine food webs. Salt marsh plants are not usually subject to herbivory and usually enter food webs through the detritivore pathway (Créach et al., 1997; Lillebø et al., 1999). Several species feed on plant detritus (Créach et al., 1997; Laffaille et al., 2002), and metals associated with such a food source may become available to deposit feeders, with a risk for deleterious effects (Weis and Weis, 2004). Working with Spartina alterniflora and Phragmites australis, Windham and co-workers (2003) calculated aboveground mercury pools to be around $0.06 \mathrm{mg} \mathrm{Hg} \mathrm{m}^{-2}$, and we observed metal concentrations comparable to those in this study. Given the similar range of mercury concentrations in the aboveground biomass of all salt marsh plants, the mercury pool associated with each plant per square meter should be equivalent and should range between 0.05$0.1 \mathrm{mg} \mathrm{Hg} \mathrm{m}^{-2}$, depending on the specific aerial biomass.

Seagrasses (Zostera noltii) showed a contrasting behavior when compared to salt marsh plants. Accumulation in aerial parts was similar to that observed for the belowground biomass, and enrichment factors were slightly higher (although not significantly). The lack of significant correlations between sediment and aboveground mercury levels suggest that there is leaf accumulation from the dissolved mercury fraction when submerged, which is in accordance with previous findings on contaminant accumulation by seagrasses (Lafabrie et al.,2007, 2008). Additionally, consistent differences were observed between the metal loads of new and old senescent leaves, probably resulting from one or a combination of several processes. Accumulation of metals could occur throughout the lifespan of the leaves, resulting in increased loads in older leaves. However, several authors have reported increased metal contents in senescent plant tissues and detritus (Weis and Weis, 2004 and references therein), as a result of microbial metabolism of the decaying litter or the adsorption of metals from the sediments. In contrast to salt marsh plants, seagrasses are actively grazed upon by several herbivore species (Heck and Valentine, 2006; MacArthur and Hyndes, 2007), while still being important in the detritus pathway (Vizzini et al., 2002). Since the aboveground (leaf) portion of the seagrass is replaced frequently, much of this material can be exported to other portions of the estuary or coastal ocean, acting as a transport agent for mercury (Kaldy, 2006).

Calculations based on the seagrass bed biomass information reported by da Silva et al. (2004) and on the mercury concentrations found in this study indicate an estimated mercury pool of $0.07 \mathrm{mg} \mathrm{Hg} \mathrm{m}^{-2}$ for $Z$. noltii, which is similar to that predicted for salt marsh plants, despite the considerably higher mercury concentrations in the seagrass. This may be due to the high aerial biomass of salt marsh plants compared to $Z$. noltii, although the mercury pool associated with the latter will be more readily available to consumers through direct grazing.

The progressive reduction of seagrass communities is a concern for many researchers (Cardoso et al., 2004; da Silva et al., 2004), and several reasons have been pointed out for this decline, 
although eutrophication is the most widely accepted (Burkholder et al., 2007). Excess dissolved nutrients promote rapid growth of opportunistic macroalgae, which compete for and reduce light availability to seagrass meadows, in a gradual plant succession that replaces rooted macrophytes with free-floating algae (Cardoso et al., 2004; Burkholder et al., 2007). In the case of the Ria de Aveiro, physical force in the system is thought to be the primary cause for the decline, namely higher water turbidity through increased tidal wave penetration (da Silva et al., 2004). However, eutrophication must be considered, given the abundant presence of macroalgae (Coelho et al., 2005). This primary producer replacement may have important implications in contaminated areas, given the different dynamics of rooted macrophytes and macroalgae.

Macroalgae were found to respond to the contamination gradient, but correlations with environmental contamination were poor overall. The high mobility of this genus may explain the poorer correlations with environmental mercury levels, since tidal transport to and from the contaminated area will influence its distribution. Through their high growth rate and metal binding capacity, macroalgae can incorporate large amounts of mercury, which can then be transported by tidal currents (mainly Enteromorpha) away from the contamination source. Our results support this hypothesis, since high mercury levels were found in algal tissue more than $10 \mathrm{~km}$ away from the contamination source (site A7). Calculations using the average mercury concentrations in the contaminated area

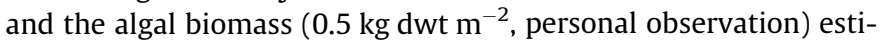
mated a pool of $0.28 \mathrm{mg} \mathrm{Hg} \mathrm{m}^{-2}$ total mercury, of which $0.010 \mathrm{mg} \mathrm{Hg} \mathrm{m}^{-2}$ is in organic form and available for consumers. Comparing these results to those found for seagrasses suggests a 4-fold increase in the total mercury pool from seagrass beds to the macroalgae-covered area and a 5-fold increase in the organic mercury pools. Considering that both macroalgae and seagrasses are grazed upon, this shift in primary producer coverage may represent an increased contamination pressure on existing herbivore communities, and given that mercury accumulates along food webs (Lawson and Mason, 1998), this pressure could be felt by the entire ecosystem. In addition, the disappearance of seagrass meadows enhances sediment erosion (Cardoso et al., 2004; Burkholder et al., 2007), resulting in an increased transport of finegrained contaminated particles to other areas of the system, which could make the confined contamination problem into a more widespread issue.

It is therefore essential to clarify the dynamics of seagrass meadows in contaminated areas and, in the case of decline, the underlying reasons for this change. The employment of active restoration techniques should be encouraged in order to reverse such a decline, at the risk of losing critical ecosystem components and of enhancing contamination problems.

\section{Acknowledgments}

This study was supported by the Portuguese Foundation for Science and Technology through the POCTI - 2010 Formação Avançada para a Ciência - Medida IV.3 (Portuguese FCT) via a PhD Grant (SFRH/BD/19509/2004) (J.P. Coelho).

\section{References}

Almeida, C.M.R., Mucha, A.P., Vasconcelos, M., 2004. Influence of the sea rush Juncus maritimus on metal concentration and speciation in estuarine sediment colonized by the plant. Environmental Science \& Technology 38, 3112-3118.

Almeida, C.M.R., Mucha, A.P., Vasconcelos, M.T.S.D., 2006. Comparison of the role of the sea club-rush Scirpus maritimus and the sea rush Juncus maritimus in terms of concentration, speciation and bioaccumulation of metals in the estuarine sediment. Environmental Pollution 142, 151-159.

Burkholder, J.M., Tomasko, D.A., Touchette, B.W., 2007. Seagrasses and eutrophication. Journal of Experimental Marine Biology and Ecology 350, 4672.
Caçador, I., Vale, C., Catarino, F., 2000. Seasonal variation of $\mathrm{Zn}, \mathrm{Pb}, \mathrm{Cu}$ and $\mathrm{Cd}$ concentrations in the root-sediment system of Spartina maritima and Halimione portulacoides from Tagus estuary salt marshes. Marine Environmental Research 49, 279-290.

Calderón, J., Ortiz-Pèrez, D., Yáñez, L., Díaz-Barriga, F., 2003. Human exposure to metals. Pathways of exposure, biomarkers of effect, and host factors. Ecotoxicology and Environmental Safety 56, 93-103.

Canário, J., Caetano, M., Vale, C., Cesário, R., 2007. Evidence for elevated production of methylmercury in salt marshes. Environmental Science and Technology 41 7376-7382.

Cardoso, P.G., Pardal, M.A., Lillebø, A.I., Ferreira, S.M., Raffaelli, D., Marques, J.C., 2004. Dynamic changes in seagrass assemblages under eutrophication and implications for recovery. Journal of Experimental Marine Biology and Ecology 302, 233-248.

Coelho, J.P., Flindt, M.R., Jensen, H.S., Lillebø, A.I., Pardal, M.A., 2004. Phosphorus speciation and availability in intertidal sediments of a temperate estuary: relation to eutrophication and annual P-fluxes. Estuarine Coastal and Shelf Science 61, 583-590.

Coelho, J.P., Pereira, M.E., Duarte, A., Pardal, M.A., 2005. Macroalgae response to a mercury contamination gradient in a temperate coastal lagoon (Ria de Aveiro, Portugal). Estuarine Coastal and Shelf Science 65, 492-500.

Coelho, J.P., Rosa, M., Pereira, E., Duarte, A., Pardal, M.A., 2006. Pattern and annual rates of Scrobicularia plana mercury bioaccumulation in a human induced mercury gradient (Ria de Aveiro, Portugal). Estuarine Coastal and Shelf Science 69, 629-635.

Conti, M.E., Cecchetti, G., 2003. A biomonitoring study: trace metals in algae and molluscs from Tyrrhenian coastal areas. Environmental Research 93, 99-112.

Créach, V., Schricke, M.T., Bertru, G., Mariotti, A., 1997. Stable isotopes and gut analyzes to determine feeding relationships in saltmarsh macroconsumers. Estuarine, Coastal and Shelf Science 44, 599-611.

da Silva, J.F., Duck, R.W., Catarino, J.B., 2004. Seagrasses and sediment response to changing physical forcing in a coastal lagoon. Hydrology and Earth System Sciences 8, 151-159.

Fitzgerald, E.J., Caffrey, J.M., Nesaratnam, S.T., McLoughlin, P., 2003. Copper and lead concentrations in salt marsh plants on the Suir Estuary, Ireland. Environmental Pollution 123, 67-74

Gosavi, K., Sammut, J., Gifford, S., Jankowski, J., 2004. Macroalgal biomonitors of trace metal contamination in acid sulfate soil aquaculture ponds. Science of the Total Environment 324, 25-39.

Heck, J.K.L., Valentine, J.F., 2006. Plant-herbivore interactions in seagrass meadows. Journal of Experimental Marine Biology and Ecology 330, 420-436.

Hung, G.A., Chmura, G.L., 2006. Mercury accumulation in surface sediments of salt marshes of the Bay of Fundy. Environmental Pollution 142, 418-431.

Kaldy, J.E., 2006. Carbon, nitrogen, phosphorus and heavy metal budgets: how large is the eelgrass (Zostera marina L.) sink in a temperate estuary? Marine Pollution Bulletin 52, 342-353.

Kuijper, D.P.J., Beek, P., van Wieren, S.E., Bakker, J.P., 2008. Time-scale effects in the interaction between a large and a small herbivore. Basic and Applied Ecology 9, 126-134.

Lafabrie, C., Pergent, G., Kantin, R., Pergent-Martini, C., Gonzalez, J.L., 2007. Trace metals assessment in water, sediment, mussel and seagrass species - Validation of the use of Posidonia oceanica as a metal biomonitor. Chemosphere 68, 20332039.

Lafabrie, C., Pergent-Martini, C., Pergent, G., 2008. Metal contamination of Posidonia oceanica meadows along the Corsican coastline (Mediterranean). Environmental Pollution 151, 262-268.

Laffaille, P., Feunteun, E., Lefebvre, C., Radureau, A., Sagan, G., Lefeuvre, J.C., 2002. Can thin-lipped mullet directly exploit the primary and detritic production of European macrotidal salt marshes? Estuarine. Coastal and Shelf Science 54, 729-736.

Lawson, N.M., Mason, R.P., 1998. Accumulation of mercury in estuarine food chains. Biogeochemistry 40, 235-247.

Leal, M.C.F., Vasconcelos, M.T., Sousa-Pinto, I., Cabral, J.P.S., 1997. Biomonitoring with benthic macroalgae and direct assay of heavy metals in seawater of the Oporto coast (northwest Portugal). Marine Pollution Bulletin 34, 1006-1015.

Lillebø, A.I., Flindt, M.R., Pardal, M.A., Marques, J.C., 1999. The effect of macrofauna, meiofauna add microfauna on the degradation of Spartina maritima detritus from a salt marsh area. Acta Oecologica-International Journal of Ecology 20, 249-258.

Lopes, C.B., Pereira, M.E., Vale, C., Lillebo, A.I., Pardal, M.A., Duarte, A.C., 2007. Assessment of spatial environmental quality status in Ria de Aveiro (Portugal). Scientia Marina 71, 293-304.

MacArthur, L.D., Hyndes, G.A., 2007. Varying foraging strategies of Labridae in seagrass habitats: herbivory in temperate seagrass meadows? Journal of Experimental Marine Biology and Ecology 340, 247-258.

Pardal, M.A., Cardoso, P.G., Sousa, J.P., Marques, J.C., Raffaelli, D., 2004. Assessing environmental quality: a novel approach. Marine Ecology Progress Series 267, $1-8$.

Pereira, M.E., Duarte, A.C., Millward, G.E., Abreu, S.N., Vale, C., 1998a. An estimation of industrial mercury stored in sediments of a confined area of the Lagoon of Aveiro (Portugal). Water Science and Technology 37, 125-130.

Pereira, M.E., Duarte, A.C., Millward, G.E., Vale, C., Abreu, S.N., 1998b. Tidal export of particulate mercury from the most contaminated area of Aveiro's Lagoon, Portugal. Science of the Total Environment 213, 157-163.

Quan, W.M., Han, J.D., Shen, A.L., Ping, X.Y., Qian, P.L., Li, C.J., Shi, L.Y., Chen, Y.Q. 2007. Uptake and distribution of $\mathrm{N}, \mathrm{P}$ and heavy metals in three dominant salt 
marsh macrophytes from Yangtze River estuary, China. Marine Environmental Research 64, 21-37.

Rainbow, P.S., Phillips, D.J.H., 1993. Cosmopolitan biomonitors of trace metals Marine Pollution Bulletin 26, 593-601.

Runcie, J.W., Riddle, M.J., 2004. Metal concentrations in macroalgae from East Antarctica. Marine Pollution Bulletin 49, 1114-1119.

Sanchez, J.M., SanLeon, D.G., Izco, J., 2001. Primary colonization of mudflat estuaries by Spartina maritima (Curtis) Fernald in Northwest Spain: vegetation structure and sediment accretion. Aquatic Botany 69, 15-25.

Tchounwou, P.B., Ayensu, W.K., Ninashvili, N., Sutton, D., 2003. Environmental exposure to mercury and its toxicopathologic implications for public health Environmental Toxicology 18, 149-175.

Thayer, G., Bjorndal, K., Ogden, J., Williams, S., Zieman, J., 1984. Role of larger herbvores in seagrass communities. Estuaries and Coasts 7, 351-376.

Thom, R., Miller, B., Kennedy, M., 1995. Temporal patterns of grazers and vegetation in a temperate seagrass system. Aquatic Botany 50, 201-205.

Válega, M., Abreu, S., Pato, P., Rocha, L., Gomes, A.R., Pereira, M.E., Duarte, C., 2006 Determination of organic mercury in biota, plants and contaminated sediments using a thermal atomic absorption spectrometry technique. Water Air and Soil Pollution 174, 223-234.
Válega, M., Lillebø, A.I., Pereira, M.E., Corns, W.T., Stockwell, P.B., Duarte, A.C., Pardal, M.A., 2008. Assessment of methylmercury production in a temperate salt marsh (Ria de Aveiro Lagoon, Portugal). Marine Pollution Bulletin 56, 153-158.

Vermaat, J.E., Verhagen, F.C.A., 1996. Seasonal variation in the intertidal seagrass Zostera noltii Hornem.: coupling demographic and physiological patterns. Aquatic Botany 52, 259-281.

Vizzini, S., Sará, G., Michener, R.H., Mazzola, A., 2002. The role and contribution of the seagrass Posidonia oceanica (L.) Delile organic matter for secondary consumers as revealed by carbon and nitrogen stable isotope analysis. Acta Oecologica 23, 277-285

Weis, J.S., Weis, P., 2004. Metal uptake, transport and release by wetland plants: implications for phytoremediation and restoration. Environment International 30, 685-700.

Weis, P., Windham, L., Burke, D.J., Weis, J.S., 2002. Release into the environment of metals by two vascular salt marsh plants. Marine Environmental Research 54, 325-329.

Windham, L., Weis, J.S., Weis, P., 2003. Uptake and distribution of metals in two dominant salt marsh macrophytes, Spartina alterniflora (cordgrass) and Phragmites australis (common reed). Estuarine, Coastal and Shelf Science 56, 63-72. 